\title{
Financial openness, volatility, and the size of productive government
}

\author{
Iñaki Erauskin
}

Received: 10 March 2009 / Accepted: 31 May 2010 / Published online: 27 July 2010 (C) The Author(s) 2010. This article is published with open access at Springerlink.com

\begin{abstract}
This paper analyzes the impact of financial openness on the size of the government in a stochastically growing small open economy when public spending is productive and volatility-reducing using a portfolio approach. The main result of the model is that economies that are more open are associated with a smaller productive public sector. The lower risk associated with more open economies due to risk diversification implies that the government is less inclined to increase the scale of its activity to maximize welfare when productive spending is also volatility-reducing. The empirical evidence based on a sample of 16 OECD countries for the period 1970-2004 broadly supports the main results of the model, even though some results are mixed.
\end{abstract}

Keywords Financial openness · Volatility - Size of government · Productive spending

JEL Classification $\mathrm{F} 41 \cdot \mathrm{F} 43$

\begin{abstract}
I deeply thank Javier Gardeazabal for all his help. I also thank an anonymous referee, the Co-Editor Claudio Michelacci, Cruz Ángel Echevarría, Asier Minondo, Jesús Vázquez, Rafael Doménech, Antonio Fatás, José García-Solanes, Salvador Ortigueira, Philippe Bacchetta, Javier Coto-Martínez, and seminar participants at the XX Congress of the European Economic Association for their very helpful suggestions and comments. The financial support of Diputación Foral de Gipuzkoa (through the Departamento para la Innovación y la Sociedad del Conocimiento, via Red Guipuzcoana de Ciencia y Tecnología) and Gobierno Vasco (through the Grant Program to support the activities of research teams from the Basque University System) is gratefully acknowledged. The remaining errors and omissions are entirely the responsibility of the author. The data used in this paper are available at http://paginaspersonales.deusto.es/ineraus/.
\end{abstract}

I. Erauskin $(\varangle)$

Facultad de CC. EE. y Empresariales-ESTE, Departamento de Economía, Universidad de Deusto, Mundaiz s/n, 20012 Donostia-San Sebastián, Spain

e-mail: inaki.erauskin@deusto.es 


\section{Introduction}

The relationship between openness and the size of the public sector has received much attention since Rodrik (1998) asked in his seminal work, "Why do more open economies have bigger governments?." His main result was that trade openness is positively related to the size of government since "government expenditures are used to provide social insurance against external risk" (Rodrik 1998, p. 997). ${ }^{1}$ While many other studies have followed suit and other studies have cast doubts on the robustness of this result, recent evidence shows that the positive association between trade openness and government size is robust across countries and over time for a large dataset of 143 countries during the period 1950-2000 (Epifani and Gancia 2009). ${ }^{2}$ Most research has naturally been focused on the impact of increasing trade openness on the size of government, usually measured as government consumption expenditure. ${ }^{3}$ However, other variants of the relationship between openness and the size of the public sector have not been widely analyzed in the literature.

Three crucial aspects of the relationship are discussed in this paper. First, financial openness is at the forefront of the analysis. Lane and Milesi-Ferretti (2007) extensively documented that cross-border holdings of assets and liabilities have increased dramatically in recent years. As Erauskin (2009, pp. 529-530) recently pointed out, "[...] while in the period 1970-1995 only $3.4 \%$ of the domestic capital in the USA was owned, on average, by foreign investors, in the recent period 1996-2004 this had reached $16.1 \%$ ". Similar numbers apply to many countries around the world: in Germany for instance, the percentage of domestic capital in the hands of foreign investors increased from $2.3 \%$ during 1970-1995 to $9.7 \%$ in the period 1996-2004; in Spain the increase was from 4.8 to $17.1 \%$." These movements imply important changes in the portfolios of countries. Thus, adopting a portfolio approach as a tool of analysis seems natural. Second, government public spending also takes the form of a production good. According to Gramlich (1994, p. 1176), Aschauer (1989) "hit the magic button" with his pioneering empirical analysis relating government spending on physical structures to slowdowns in productivity. Since then, the analysis of the impact of productive spending on the economy has become an issue of concern, but not so in the literature that has theoretically and empirically analyzed the relationship between openness and the size of government. ${ }^{4}$ Third, the size of the public sector plays a stabilizing role in an economy where risk is present. As Andrés et al. (2008, p. 572) recently discussed, "There is substantial evidence that countries or regions with large governments display less volatile economies, as shown in Galí (1994) and Fatás and Mihov (2001)."5

\footnotetext{
1 The pioneer work on the "compensation hypothesis" (as it has become known) goes back at least to Cameron (1978).

2 Liberati (2007) and Epifani and Gancia (2009) provide good reviews of the literature.

3 Government consumption expenditure absorbs an important share of the government budget.

${ }^{4}$ An important exception is the theoretical work by Turnovsky (1999), as it will be shown below.

5 This is why, as Andrés et al. (2008, p. 572) emphasize, "we [they] take as given that the size of governments is inversely correlated with the volatility of business cycles and we look for an explanation" in their paper.
} 
Liberati (2007) lately reminded us that, from a theoretical perspective, openness can be associated with a larger or smaller public sector. ${ }^{6}$ According to the compensation hypothesis, economies that are more open have a larger public sector to compensate for higher external risk. In contrast, the efficiency hypothesis ${ }^{7}$ posits that more open economies are associated with a smaller public sector due to an increased mobility of inputs. Furthermore, "as it stands, [...] the empirical literature on the relationship between capital openness and government size is not conclusive, as different studies support a positive relation, the absence of any relation or a negative relation." (Liberati 2007, pp. 218-219). Thus, Liberati (2007, p. 215) shows that "capital openness is significantly and negatively related to government expenditures in line with the conventional wisdom that capital mobility may undermine the ability of governments to maintain larger public sectors". 8

In standard (i.e., static and/or deterministic) models analyzing tax competition, a "race to the bottom" appears to take place. Higher tax rates on mobile inputs, such as capital for instance, in the domestic economy would make capital outflow enormously to other countries (or regions) when international capital mobility is high, as the tax rates would be too low for investors seeking the highest return. Therefore, this literature suggests that more open economies that thus suffer more tax competition would be associated with a smaller public sector. However, setting higher capital tax rates in the domestic economy may not create such an enormous capital outflow if countries want to hold a well-diversified portfolio. In fact, recent research pursued by Koethenbuerger and Lockwood (2010, p. 202) claims that "Shocks dampen down tax competition and may raise taxes above the centralized level when the government provides a public consumption good." A particular passage of this work is quite illustrative (Koethenbuerger and Lockwood 2010, p. 192): "So, if taxes are not too different, the household located in one region will want to invest some of its accumulated capital in all regions. This in turn generates a negative fiscal externality: an increase in the capital tax in any "foreign" region reduces the return on capital invested in that region. Specifically, because the "home" household will not wish to withdraw all of its savings from the foreign region in response to higher taxes, in order to maintain a diversified portfolio, its interest income will go down. The key point is that this negative "rate-of-return" externality offsets the usual positive fiscal externality arising from mobile capital (i.e. that an increase in the foreign region's tax leads to a capital outflow from the foreign region to the home region). This implies that when the second externality dominates, taxation under decentralization will be higher, and growth lower, than with centralization." Therefore, tax competition does not necessarily imply excessively low tax rates and thus a smaller government in richer,

\footnotetext{
6 For instance, see Garrett (1995), and Schulze and Ursprung (1999) for reviews on this issue.

7 The efficiency hypothesis is also known as the conventional wisdom.

8 Erauskin (2010) has also offered support for a positive relationship between financial openness and the size of government, assuming that government expenditure is utility-enhancing (and, therefore, not productive). Financial integration allows an open economy to diversify some of the country-specific risk. This implies a reduction in savings and an increase in private consumption, which, in turn, raises public consumption since it complements private consumption, i.e., an open economy implies a higher size of the public sector.
} 
stochastic settings. However, it should be noted that the above argument may not be applicable to productive public spending when the variance of shocks is sufficiently small (Koethenbuerger and Lockwood 2010, p. 201).

This paper analyzes the impact of financial openness on the size of the productive public sector using a portfolio approach. The model employed is a slightly modified version of that developed by Turnovsky (1999) for a stochastically growing small open economy in continuous time, where government spending is productive (Barro 1990) and volatility-reducing. Indeed, it is in this last feature that our paper departs critically from Turnovsky (1999) to capture the stabilizing role of government. ${ }^{9}$ The main result of our model is that more open economies are associated with a smaller productive public sector. The lower volatility associated with more open economies due to risk diversification implies that governments are less inclined to increase the scale of their activity to maximize welfare, given that productive spending is also volatility-reducing. We find that the empirical evidence based on a sample of 16 OECD countries for the period 1970-2004 broadly supports the result that more open economies are associated with a lower size of the productive public sector, even though some results are mixed.

The finding that more open economies tend to be less volatile should be taken with some caution. Our sample includes only 16 developed countries. These countries have overall well-functioning financial markets. ${ }^{10}$ Thus, achieving less volatility in such an open economy is more likely. However, this may not be the cased for many developing countries. As Kose et al. (2006, pp. 21-22) point out, "Turning to volatility more broadly, there has been a well-documented trend decline in macroeconomic volatility in most of the major industrial economies since the mid-1980s (Doyle and Faust 2005), although the reasons for this decline are still a matter of debate. Output volatility seems to have been on a declining trend in emerging market and developing economies as well. However, the existing evidence based on papers using a variety of regression models, different country samples and time periods leads to the conclusion that there is no systematic empirical relationship between financial openness and output volatility, which is, in a sense, consistent with the predictions of theory."11

A critical difference of this study compared to other studies on how financial openness and the size of the productive government are measured is worth mentioning at this stage. Since the analysis pursued in this paper is based on a portfolio approach, the degree of financial openness is conveniently characterized by the size of portfolio shares. On the one hand, financial integration is understood (rather narrowly) as the share of holdings of foreign capital owned by the domestic economy over domestic wealth. On the other hand, it is measured (rather broadly) as the net foreign asset

\footnotetext{
9 A two-country model (with a much higher degree of complexity) can be found in Erauskin (2004).

10 This is, of course, doubtful as regards the current crisis. However, our sample is "restricted" to the period 1970-2004, as indicated above.

11 Additionally, Kose et al. (2006, p. 21) claim that "In sum, there is little formal empirical evidence to support the oft-cited claims that financial globalization in and of itself is responsible for the spate of financial crises that the world has seen over the last three decades. Of course, as we will discuss in more detail below, the interaction between capital account liberalization and other policy choices (e.g., fixed exchange rate regimes that are not well supported by other macroeconomic policies) could, under certain circumstances, spell trouble for a developing economy."
} 
position with respect to domestic wealth. The size of the productive government is also expressed as a fraction of wealth. Therefore, the measures for the degree of financial openness and the size of the productive government are different from the variables used in the literature. Previous studies have usually chosen the sum of (some) domestic and foreign assets and liabilities over gross domestic product (GDP) as a measure of financial openness. ${ }^{12}$ There are two reasons for expressing variables as a fraction of wealth in this paper. First, measuring financial openness and the size of the productive government in this (different and "novel") way is a direct implication of the model employed. Second, the recent availability of international investment position statistics allows the direct estimation of the variables required by the model, such as financial openness (either in a narrow or in a broad sense) and the size of the productive government. $^{13}$

The paper is organized as follows. Some empirical evidence is offered in Sect. 2 regarding the relationship between the degree of financial openness and the size of the productive public sector. In Sect. 3 a stochastic growth model of a small open economy is characterized. The welfare-maximizing size of the public sector is derived in Sect. 4. Finally, we conclude.

\section{Empirical evidence}

We present some evidence on the negative relationship between the degree of financial openness and the size of the productive public sector with respect to domestic wealth by focusing on 16 OECD countries for the period 1970-2004. ${ }^{14}$ As mentioned above, two measures for the degree of financial openness are considered:

- Measure 1 (broad): The share of domestic wealth materialized in foreign assets, i.e., the net foreign asset position, which is calculated as the domestic holdings on foreign capital plus the net lending position abroad minus foreign holdings of domestic capital, divided by domestic wealth. Positive values imply a creditor position for the country, and negative values imply a debtor position.

- Measure 2 (narrow): The share of the domestic portfolio materialized in foreign capital.

Thus, higher values of the measure indicate a higher degree of financial openness.

The negative association can be tested with the following regression equation

$$
\left(\frac{G}{W}\right)_{c t}=a_{0}+a_{1} n_{F, c t}+u_{c t},
$$

where $(G / W)_{c t}$ denotes the size of the productive public sector to wealth ratio for country $c$ in period $t, n_{F, c t}$ denotes the degree of financial openness for country $c$ in

\footnotetext{
12 See Lane and Milesi-Ferretti (2007) and Liberati (2007), for instance.

13 The data on international investment positions are mainly provided by the International Monetary Fund, and Lane and Milesi-Ferretti (2007).

${ }^{14}$ See Appendix A for the data sources regarding the empirical evidence.
} 
Table 1 Financial openness (measure 1) and the size of the productive public sector

\begin{tabular}{llll}
\hline & $\begin{array}{l}\text { Pooled } \\
\text { regression }\end{array}$ & $\begin{array}{l}\text { Between } \\
\text { regression }\end{array}$ & $\begin{array}{l}\text { Within } \\
\text { regression }\end{array}$ \\
\hline Net foreign asset position & $-0.0005(0.0025)$ & $0.0071(0.0119)$ & $-0.0081(0.0049)$ \\
$R^{2}$ & 0.0001 & 0.0249 & 0.0175 \\
No. of observations & 552 & 16 & 552 \\
\hline
\end{tabular}

Standard errors are in parentheses

Sources International Monetary Fund's International Financial Statistics (IMFIFS), World Bank's World Development Indicators (WBWDI), Lane and Milesi-Ferretti (2007), AMECO database,

Nehru and Dhareshwar (1993) and our own elaboration

Table 2 Financial openness (measure 2) and the size of the productive public sector

\begin{tabular}{llll}
\hline & $\begin{array}{l}\text { Pooled } \\
\text { regression }\end{array}$ & $\begin{array}{l}\text { Between } \\
\text { regression }\end{array}$ & $\begin{array}{l}\text { Within } \\
\text { regression }\end{array}$ \\
\hline Portfolio share & $-0.0183(0.0018)$ & $-0.0159(0.0138)$ & $-0.0192(0.0038)$ \\
$R^{2}$ & 0.1245 & 0.0861 & 0.1422 \\
No. of observations & 552 & 16 & 552 \\
\hline
\end{tabular}

Standard errors are in parentheses

Sources IMFIFS, WBWDI, Lane and Milesi-Ferretti (2007), AMECO

Nehru and Dhareshwar (1993) and our own elaboration

period $t$, and $u_{c t}$ is the error term for country $c$ in period $t$. Under the null hypothesis that a more open economy should have a smaller productive public sector, the coefficient $a_{1}$ should be negative.

Table 1 shows the results using ordinary least squares (OLS) for the net foreign asset position (measure 1). The point estimate $a_{1}$ for the pooled regression is negative at -0.0005 , but we cannot reject that the value of parameter $a_{1}$ is equal to zero. The pooled estimate uses all available variation in net foreign asset positions and public sector sizes. The between-group estimates (i.e., based on the mean values of the variables of the group) and the within-group estimates (also called fixed-effects estimators, i.e., in terms of deviations from the mean values of the variables of the group) offer more information about whether the pooling estimate is driven by persistent (the former case) or transitory (the latter case) differences in net foreign asset positions and public sector sizes. These estimates are also shown in Table 1. While the within-group estimate for the coefficient capturing financial openness is found again to be negative, the null cannot be rejected. In contrast, the between-group estimate shows a positive coefficient. Focusing on the shares of foreign capital over domestic wealth as the degree of financial openness (measure 2), we find that the results are broadly consistent with a negative relationship between financial openness and the size of the productive government, as exhibited in Table 2, even though the null cannot be rejected for the between-group estimate. Consequently, these results seem to suggest a negative relationship between financial openness and the size of the productive public sector, even though the evidence is not completely satisfactory. 
Table 3 Financial openness (measure 1) and the size of the productive public sector (with control variables)

\begin{tabular}{llll}
\hline & $\begin{array}{l}\text { Pooled } \\
\text { regression }\end{array}$ & $\begin{array}{l}\text { Between } \\
\text { regression }\end{array}$ & $\begin{array}{l}\text { Within } \\
\text { regression }\end{array}$ \\
\hline Net foreign asset position & $-0.0072(0.0017)$ & $-0.0038(0.0172)$ & $-0.0127(0.0033)$ \\
Time trend & $-0.00004(0.00004)$ & & -0.00010 .0002 \\
Current account (\%GDP) & $-0.0090(0.0069)$ & $0.1047(0.0660)$ & $-0.0330(0.0010)$ \\
Population & $1.68 \mathrm{e}-11(3.95 \mathrm{e}-12)$ & $1.07 \mathrm{e}-11(1.99 \mathrm{e}-11)$ & $8.13 \mathrm{e}-11(4.54 \mathrm{e}-11)$ \\
Population growth & $-0.0010(0.0004)$ & $0.0030(0.0032)$ & $-0.0007(0.0008)$ \\
GDP per capita & $-3.47 \mathrm{e}-07(7.48 \mathrm{e}-08)$ & $-6.18 \mathrm{e}-07(3.43 \mathrm{e}-07)$ & $-2.22 \mathrm{e}-07(4.80 \mathrm{e}-07)$ \\
GDP per capita growth & $0.0002(0.0001)$ & $0.0028(0.0043)$ & $0.0002(0.0001)$ \\
$R^{2}$ & 0.1718 & 0.3906 & 0.2777 \\
No. of observations & 470 & 16 & 470 \\
\hline
\end{tabular}

Standard errors are in parentheses

Sources IMFIFS, WBWDI, Lane and Milesi-Ferretti (2007), AMECO

Nehru and Dhareshwar (1993) and our own elaboration

Since other variables may influence the relationship, some control variables were incorporated into the regression equation. ${ }^{15}$ They include population and output per capita (both in terms of levels and in terms of growth rates) so that the size of the economy and possible pressures on government spending are considered. Current account balance (as a percentage of the GDP) is considered a potential influence on the size of the public sector. Finally, a time trend that can capture possible upward or downward movements in economic variables is also included. Note that due to data availability the period analyzed is now restricted to 1975-2004 for the same set of countries. When control variables are added to the regression, for the case in which net foreign asset position is considered, these variables have substantial effects on the estimates for coefficient $a_{1}$, as shown in Table 3 . They all yield negative values for the net foreign asset position coefficient, $a_{1}$, and the null hypothesis can thus be comfortably rejected, except for the between-group estimate. When shares of domestic holdings of foreign capital over domestic wealth are regressed, we still find negative values for the estimate $a_{1}$ (although the null cannot be rejected), while the within-group estimate becomes positive (Table 4).

In summary, the evidence broadly suggests a negative relationship between the degree of financial openness and the size of the productive public sector when control variables are included for the net foreign asset position (measure 1) and when controls are not taken into account for portfolio shares (measure 2). However, the empirical support is somewhat mixed in other model configurations.

\section{The model}

The analysis is based on a stochastically growing small open economy in continuous time where government spending is productive. ${ }^{16}$ The model in this paper is a

\footnotetext{
15 See, for instance, Liberati (2007, pp. 227-230).

16 Barro (1990) is the original reference for the deterministic model.
} 
Table 4 Financial openness (measure 2) and the size of the productive public sector (with control variables)

\begin{tabular}{llll}
\hline & $\begin{array}{l}\text { Pooled } \\
\text { regression }\end{array}$ & $\begin{array}{l}\text { Between } \\
\text { regression }\end{array}$ & $\begin{array}{l}\text { Within } \\
\text { regression }\end{array}$ \\
\hline Portfolio share & $-0.0070(0.0022)$ & $-0.0118(0.0135)$ & $0.0028(0.0063)$ \\
Time trend & $9.38 \mathrm{e}-07(3.94 \mathrm{e}-05)$ & & $-3.34 \mathrm{e}-05(0.0002)$ \\
Current account (\%GDP) & $-0.0112(0.0075)$ & $0.0970(0.0581)$ & $-0.0399(0.0141)$ \\
Population & $1.06 \mathrm{e}-11(3.81 \mathrm{e}-12)$ & $5.94 \mathrm{e}-12(1.54 \mathrm{e}-11)$ & $9.49 \mathrm{e}-11(5.09 \mathrm{e}-11)$ \\
Population growth & $-0.0006(0.0004)$ & $0.0027(0.0029)$ & $-0.0008(0.0006)$ \\
GDP per capita & $-2.78 \mathrm{e}-07(7.80 \mathrm{e}-08)$ & $-4.91 \mathrm{e}-07(3.42 \mathrm{e}-07)$ & $-3.95 \mathrm{e}-07(5.26 \mathrm{e}-07)$ \\
GDP per capita growth & $0.0002(0.0001)$ & $0.0025(0.0041)$ & $0.0002(0.0001)$ \\
$R^{2}$ & 0.1667 & 0.4352 & 0.2261 \\
No. of observations & 470 & 16 & 470 \\
\hline
\end{tabular}

Standard errors are in parentheses

Sources IMFIFS, WBWDI, Lane and Milesi-Ferretti (2007), AMECO

Nehru and Dhareshwar (1993) and our own elaboration

slightly modified version of Turnovsky (1999) model, but government spending is volatility-reducing rather than volatility-enhancing. The country produces and consumes a single traded good. The representative agent holds two assets in the portfolio: domestic capital, $K$, and traded bonds, $B$. Please note that positive values in the holdings of traded bonds, $B>0$, denote a creditor country, and negative values denote a debtor country.

The flow of output, $d Y$, is determined by the stock of domestic capital, $K$, and the flow of productive government spending, $G$, in accordance with the following stochastic production function ${ }^{17}$

$$
d Y=\alpha G^{\beta} K^{1-\beta} d t+K d y ; 0<\beta<1
$$

where $\alpha$ is the level of technology, and $d y$ represents a proportional domestic productivity shock. More precisely, $d y$ is the increment of a stochastic process $y$. These increments are temporally independent and normally distributed. They satisfy $E(d y)=0$ and $E\left(d y^{2}\right)=\sigma_{y}^{2} d t .{ }^{18}$ Please note that $d Y$ indicates the flow of production, instead of $Y$, as is custom in stochastic calculus. For convenience, we omit formal references to time, although these variables depend on time. Equation (1) reflects that the mean rate of output flow, $\alpha G^{\beta} K^{1-\beta}$, is subject to a positive, but diminishing, marginal physical product, in terms of both the flow of productive government spending, $G,{ }^{19}$ and the stock of domestic capital, $K$, and constant returns to scale in these two factors of

\footnotetext{
17 Corsetti (1997), for example, develops a stochastic version of the Barro model where productive public spending has an external effect on labor productivity.

18 I.e., the production flow follows a Brownian motion with $\operatorname{drift} \alpha G^{\beta} K^{1-\beta}$ and with variance $K^{2} \sigma_{y}^{2}$.

19 Please note that we introduce the flow of production goods provided by the public sector and not the stock of accumulated public capital stock. Postulating it as a stock (being the spending in public physical structures) would lead to a transitional dynamics equilibrium. The literature has usually opted to postulate it as a flow to be analytically tractable.
} 
production jointly. The model abstracts labor so that private capital can be interpreted broadly to include both human and physical capital (Rebelo 1991).

The public sector purchases part of the private flow of production and utilizes it to supply a productive infrastructure that is a pure public good to the representative agent according to

$$
d G=G d t+G^{\prime} d y
$$

where $G$ denotes the deterministic rate of public spending over the period $d t$ and $G^{\prime}$ denotes the stochastic flow of public spending as a proportion of stochastic output shock. The spending of the public sector, $G$ and $G^{\prime}$, is assumed to be a fraction, $g$, of the flow of output with respect to both deterministic and stochastic rates as given by Eq. (1), where $g$ denotes the size of the public sector:

$$
\begin{aligned}
G & =g \alpha G^{\beta} K^{1-\beta} \\
G^{\prime} & =g K
\end{aligned}
$$

In summary, the Eqs. (2), (3 ), and (4) altogether imply that a fraction $g$ of the deterministic rate of output flow, $\alpha G^{\beta} K^{1-\beta}$, and a fraction $g$ of the stochastic rate of output flow, $K d y$, are devoted to productive public spending.

Please note that only the deterministic component of government expenditure, $G$, is productive in the production function (1). This is a reasonable assumption since public spending takes some time to become readily available as a production good. Additionally, the productivity shock $d y$ in Eq. (1) is proportional to the stock of capital $K$, but not to the level of public spending $G$. This is an important assumption since it implies that greater government spending stabilizes the flow of output; see Eqs. (2) and (4). As Andrés et al. (2008, p. 572) recently described, "large governments are associated with less volatile economies" across countries and regions. The volatility-reducing capacity of government spending is well documented in the literature [Galí (1994), and Fatás and Mihov $\left.(2001)^{20}\right]$. The inclusion of this stabilizing role of government distinguishes this paper from the theoretical analysis of Turnovsky (1999).

Inserting the value of the deterministic component of government expenditure $G$ in Eq. (3) into Eq. (1), the production function becomes

$$
d Y=\left(\alpha g^{\beta}\right)^{1 /(1-\beta)} K d t+K d y
$$

For convenience, we let

$$
\Omega(g) \equiv\left(\alpha g^{\beta}\right)^{1 /(1-\beta)} \equiv \alpha G^{\beta} K^{1-\beta} / K, \quad \Omega^{\prime}>0
$$

denote the equilibrium average product of capital. The production function shown in Eq. (5) shows that the productivity of capital increases with the size of government

\footnotetext{
20 Rodrik (1998, p. 1028) also finds that "Governments appear to have sought to mitigate the exposure to risk by increasing the share of domestic output they consume."
} 
$g$. Using the notation (6) in Eq. (2), which captures the evolution of public spending, Eq. (2) becomes

$$
d G=g K[\Omega(g) d t+d y] .
$$

In addition to domestic capital, the portfolio of the representative agent is invested in traded bonds, which are assumed to be perpetuities, the price of which is $E$ in terms of the traded good. The price of bonds is assumed to follow a geometric Brownian motion as follows

$$
\frac{d E}{E}=\varepsilon d t+d e,
$$

where $\varepsilon$ is the instantaneous expected rate of change in the relative price of the good and $d e$ is an increment of the stochastic process $e$. These increments are temporally independent and normally distributed. They satisfy $E(d e)=0$ and $E\left(d e^{2}\right)=\sigma_{e}^{2} d t$. They are assumed to be exogenously given in a small open economy. The real rate of return for foreign bonds as expressed in terms of the traded good as the numeraire, $d R_{F}$, is equal to

$$
d R_{F}=r_{F} d t+d u_{F} ; \quad r_{F} \equiv i^{*}+\varepsilon ; \quad d u_{F} \equiv d e,
$$

where the foreign real interest rate, $i^{*}$, is exogenously given. For simplicity, the stochastic shocks $d y$ and $d e$ are assumed to be uncorrelated.

Therefore, the representative agent's wealth constraint will thus be

$$
W=K+E B
$$

where $W$ is real wealth and is expressed in terms of the numeraire.

The preferences of the representative agent are represented by an isoelastic intertemporal utility function where utility is obtained from consumption, $C$, as follows

$$
E_{0} \int_{0}^{\infty} \frac{1}{\gamma} C^{\gamma} e^{-\beta t} d t ; \quad-\infty<\gamma<1
$$

The welfare of the representative agent in period 0 is the expected value of the discounted sum of instantaneous utilities conditioned on the set of disposable information in period 0. Parameter $\beta$ is a positive subjective discount rate (or rate of time preference). In the isoelastic utility function, the Arrow-Pratt coefficient of relative risk aversion is given by the expression $1-\gamma$. The utility function becomes logarithmic when $\gamma=0 .^{21}$ Restrictions on the utility function are necessary to ensure concavity with respect to consumption.

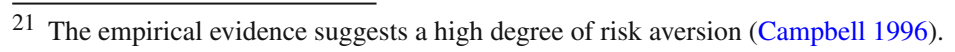


The representative agent consumes at a deterministic rate $C(t) d t$ in the instant $d t$ and must pay any corresponding taxes. Thus the dynamic budget restriction can be expressed, using Eqs. (5), (8), (9), and (10), as

$$
d W=\left[\Omega(g) K+(E B)\left(i^{*}+\varepsilon\right)\right] d t+[\alpha K d y+(E B) d e]-C d t-d T,
$$

where $d T$ denotes the taxes the representative agent must pay to the public sector. We assume that the collection of taxes exactly offsets public spending

$$
d T=d G
$$

Thus, the public sector balances its budget continuously.

Combining the Eqs. (5), (7), and (13), and inserting them into the budget constraint (12), we obtain the restrictions on the economy's resources as follows,

$$
\begin{aligned}
d W= & {\left[(1-g) \Omega(g) K+(E B)\left(i^{*}+\varepsilon\right)-C\right] d t } \\
& +[(1-g) K d y+(E B) d e]
\end{aligned}
$$

Returning to Eq. (10), if we define the following variables for the representative agent

$$
\begin{aligned}
n_{K} \equiv \frac{K}{W}= & \text { share of the portfolio materialized } \\
& \text { in domestic capital, } \\
n_{F} \equiv \frac{E B}{W}= & \text { share of the portfolio materialized } \\
& \text { in foreign bonds, }
\end{aligned}
$$

the wealth equation (10) can be expressed more succinctly as

$$
1=n_{K}+n_{F}
$$

Inserting (15) into the budget constraint (14) we obtain the following dynamic restriction on the economy's resources

$$
\frac{d W}{W}=\left[(1-g) \Omega(g) n_{K}+\left(i^{*}+\varepsilon\right) n_{F}-\frac{C}{W}\right] d t+\left[n_{K}(1-g) d y+n_{F} d e\right]
$$

This equation can be shown as

$$
\frac{d W}{W}=\psi d t+d w
$$


where the deterministic and stochastic parts of the accumulation rate of assets, $d W / W$, are expressed as follows,

$$
\begin{gathered}
\psi \equiv n_{K}\left[(1-g) \Omega(g) n_{K}-\left(i^{*}+\varepsilon\right)\right]+\left(i^{*}+\varepsilon\right)-\frac{C}{W} \equiv \rho-\frac{C}{W}, \\
d w \equiv n_{K}[(1-g) d y-d e]+d e
\end{gathered}
$$

where $\rho \equiv(1-g) \Omega(g) n_{K}+\left(i^{*}+\varepsilon\right) n_{F} \equiv n_{K}\left[(1-g) \Omega(g)-\left(i^{*}+\varepsilon\right)\right]+\left(i^{*}+\varepsilon\right)$ denotes the gross rate of return of the asset portfolio.

Since our analysis is mainly concerned with the impact of financial openness on the size of the public sector, we shall restrict our attention to the case in which the public sector acts as a central planner. The objective of the central planner is to choose the consumption patterns and portfolio shares that maximize the expected value of the intertemporal utility function (11) subject to $W(0)=W_{0},(16),(17)$ and (18). This optimization is thus a stochastic optimum control problem. ${ }^{22}$ Initially, we assume that the public sector sets an arbitrarily exogenous size of the public sector, $g$. We analyze the case in which this size is optimally chosen in Sect. 4.

The macroeconomic equilibrium is derived in Appendix B. The equilibrium rate of wealth accumulation in this small open economy follows the stochastic process

$$
\frac{d W}{W}=\psi d t+d w
$$

where the deterministic and stochastic components are, respectively,

$$
\begin{gathered}
\psi=\frac{1}{1-\gamma}\left\{\rho-\beta-0.5 \gamma(1-\gamma) \sigma_{w}^{2}\right\}, \\
d w=(1-g) n_{K} d y+n_{F} d e .
\end{gathered}
$$

The equilibrium portfolio shares and the consumption-wealth ratio in the economy are jointly determined by Eqs. (38), (39), and (40),

$$
\begin{gathered}
n_{K}=\frac{(1-g) \Omega(g)-\left(i^{*}+\varepsilon\right)}{(1-\gamma) \Delta}+\frac{\sigma_{e}^{2}}{\Delta}, \\
n_{F}=1-n_{K}, \\
\frac{C}{W}=\frac{1}{1-\gamma}\left\{\beta-\gamma \rho+0.5 \gamma(1-\gamma) \sigma_{w}^{2}\right\},
\end{gathered}
$$

where

$$
\begin{aligned}
\Delta & =(1-g)^{2} \sigma_{y}^{2}+\sigma_{e}^{2}, \\
\sigma_{w}^{2} & =(1-g)^{2} n_{K}^{2} \sigma_{y}^{2}+n_{F}^{2} \sigma_{e}^{2} .
\end{aligned}
$$

\footnotetext{
22 To solve problems of stochastic optimum control see, for example, Kamien and Schwartz (1991, sect. 22), Malliaris and Brock (1982, ch. 2), Obstfeld (1992), or Turnovsky (1997, ch. 9; 2000, ch. 15).
} 
are Eqs. (41) and (42), respectively. The Eqs. (38), (39), (40), (41), and (42) can be found in Appendix B. The optimal portfolio shares, given by Eqs. (21) and (22), are standard in the literature. Portfolio shares are determined by a speculative term proportional to the expected difference in the rates of return between assets; the return on capital is equal to the marginal product of capital less the fraction devoted to government spending. The second term is a hedging component and it captures risk diversification between assets. Although with more general utility functions, portfolio shares and the consumption-wealth ratio will become functions of time, in this model, these variables are constant because the utility function exhibits constant relative risk aversion, the production function is linear, and the mean and variances of the underlying stochastic processes are stationary. The equilibrium is characterized by balanced real growth, where all real assets grow at the same rate, and by constant portfolio shares and consumption-wealth ratio. Please note that neither the expression $\Delta$ nor the variance of the growth rate of assets $\sigma_{w}^{2}$ shown in Eqs. (24) and (25) can be negative. Appendix $\mathrm{C}$ shows that the second-order conditions are satisfied.

Economic welfare is given by the value function used to solve the intertemporal optimization problem given by Eq. (44) in Appendix C

$$
V(W)=\frac{1}{\gamma}\left(\frac{C}{W}\right)^{\gamma-1} W^{\gamma}
$$

If Eq. (26) is differentiated, we obtain the following function,

$$
\frac{d V}{V}=(\gamma-1) \frac{d(C / W)}{C / W} .
$$

Note that only changes in the optimal consumption-wealth ratio given by Eq. (23) have an impact on economic welfare. Thus, a higher optimal consumption-wealth ratio can improve or deteriorate the welfare of the representative agent. Since $C$ / $W$ is positive in Eq. (26), the value function can take either positive or negative values, depending on the sign of the coefficient $\gamma$ subject to $\gamma V(W)>0$. When $\gamma<0$, any factor that increases the optimal consumption-wealth ratio increases welfare. For instance, a higher subjective discount rate, which increases the optimal consumption-wealth ratio, generates higher welfare for $\gamma<0$.

\section{The optimal size of the public sector}

A key issue that this paper aims to address is the impact of financial openness on the size of the productive public sector. We use the share of the domestic portfolio materialized in foreign bonds, $n_{F}=1-n_{K}$, to approximate the degree of financial openness of the domestic economy. Higher fractions of wealth invested in foreign bonds, $n_{F}$, indicate a higher degree of financial openness. A closed economy implies that $n_{F}=0$, i.e., that domestic wealth is completely invested in domestic capital, $n_{K}=1$. An important feature of the model employed is that in contrast to previous theoretical work (Turnovsky 1999), we allow government spending to reduce volatility. Thus, the size 
of the public sector plays a stabilizing role in the economy. This assumption is broadly supported in the literature; "Empirical evidence suggests that larger governments have a stabilizing effect on consumption and output, that is, countries with large governments display less volatile business cycles" (Andrés et al. 2008, p. 590). ${ }^{23}$ Therefore, since an open economy allows more risk diversification than a closed economy, the role of government in the mitigation of volatility is potentially lower (higher) in an open (a closed) economy. Please note that volatility is defined as the variance of the growth rate $\sigma_{w}^{2}$.

Differentiating Eq. (25) with respect to the size of the public sector $g$, it is easy to see that

$$
\frac{\partial \sigma_{w}^{2}}{\partial g}=-2(1-g) n_{K}^{2} \sigma_{y}^{2} .
$$

Thus, increasing the size of government reduces volatility. Additionally, higher shares of domestic wealth materialized in domestic capital (i.e., lower degrees of financial openness) result in a higher impact of increased government size on volatility.

An exogenous size for productive government spending has been assumed thus far. We now turn to the size of the public sector $g$ that maximizes welfare, i.e., the optimal size of the public sector. A crucial characteristic of the model is that productive government expenditure is also volatility-reducing. Formally, the expression on the right hand side of the Bellman equation (31) in Appendix B is partially differentiated with respect to $g$ to calculate the optimal size of the public sector, $\widehat{g}$, as

$$
[\beta-\widehat{g}]+\left[(1-\gamma) n_{K}(1-\widehat{g}) \sigma_{y}^{2}\right]=0
$$

In Eq. (27) we observe two effects. The first term in the brackets reflects the productive effect of increasing the size of government whereas the second captures the volatilityreducing effect. Equation (27) can be rearranged to show (implicitly) that the optimal size of the public sector in an open economy is equal to

$$
\widehat{g}=\beta+\left[(1-\gamma) n_{K}(1-\widehat{g}) \sigma_{y}^{2}\right] \text {. }
$$

If there is no risk in Eq. (28), the optimal size of the public sector is equal to $\widehat{g}=\beta$, which is the share of government spending in the production function. This result was already found by Barro (1990) and Turnovsky (1999). ${ }^{24}$ However, the introduction of production risk increases the optimal size of the public sector, as an increase in production risk increases the variance of the return of domestic capital. Thus, the public sector is more inclined to increase its size to take advantage of the volatility-reducing capacity of public spending. Therefore, increasing volatility leads governments to expand the size of the public sector to maximize welfare. In contrast, volatility-enhancing spending encourages a reduction in the size of government, as in Turnovsky (1999).

\footnotetext{
23 See Galí (1994), Rodrik (1998), and Fatás and Mihov (2001), for instance.

24 The optimal size of government $\widehat{g}$ can be easily shown to have an interior solution.
} 
Moreover, Eq. (28) implies that the optimal size of the public sector in a closed economy, i.e., $n_{K}=1$, is given by

$$
\widehat{g}=\beta+\left[(1-\gamma)(1-\widehat{g}) \sigma_{y}^{2}\right]
$$

Comparing Eqs. (28) and (29), we observe that a more open economy will have a smaller productive public sector if and only if $n_{K}<1$ (or $n_{F}>0$ ), i.e., if the country is a net creditor vis-à-vis the rest of the world. The intuition behind this result lies in the association of a more open economy with a lower volatility; the public sector is less inclined in an open economy to increase the size of government to maximize welfare. This is again in stark contrast with the conclusion reached by Turnovsky (1999) in the volatility-enhancing case. In summary, the result from Eq. (28) provides a rigorous demonstration of the negative relationship between financial openness and the size of the productive public sector when government spending is volatility-reducing. The result hinges on two crucial elements: risk diversification and the stabilizing role of the productive public sector.

\section{Conclusions}

The relationship between openness and the size of government has been extensively researched since Rodrik (1998) published his seminal paper. The literature has mainly focused on trade openness and government consumption expenditure. However, the research on other variants in the relationship between openness and the size of government has been relatively limited.

This paper is centered on three crucial aspects of this relationship: financial openness (cross-border holdings of capital have increased enormously in recent years), the importance of productive public spending, and the stabilizing role of government size (supported by substantial empirical evidence). This paper studies the impact of financial openness on the size of the public sector using a portfolio approach. The model employed is a slightly modified version of that developed by Turnovsky (1999); it assumes a stochastic small open economy in continuous time in which government spending is productive (Barro 1990) and volatility-reducing. It is in this last feature that our paper departs crucially from Turnovsky (1999) analysis to capture the stabilizing role of government. The main result of our model is that more open economies are associated with a smaller productive public sector. The lower risk associated with more open economies through risk diversification implies that the government is less inclined to increase the scale of its activity to maximize welfare when productive spending is also volatility-reducing. The empirical evidence based on a sample of 16 OECD countries for the period 1970-2004 broadly supports the main results of the model, even though there are some mixed results. However, the fact that more open economies tend to be less volatile should be taken with some caution when the model is applied to developing countries. Further research is required to analyze whether the negative relationship between financial openness and the productive size of government also holds for developing countries. 


\section{Appendix A: Data sources}

The data set used to test the relationship between the degree of financial openness and the size of the productive public sector includes the following 16 OECD countries over the period 1970-2004: Austria, Australia, Belgium, Canada, Denmark, Finland, France, Germany, Greece, Italy, Japan, Spain, Portugal, Sweden, the United Kingdom, and the United States. The data on private consumption, and the size of the public sector are based on the World Bank's World Development Indicators (WBWDI). International investment position statistics were obtained from the International Monetary Fund's International Financial Statistics (IMFIFS). Additionally, as data on international investment positions are incomplete or missing for many countries before 19801986, Lane and Milesi-Ferretti (2007) provide an excellent source of data for those years. ${ }^{25}$ The net foreign asset position is equal to the domestic holdings on foreign capital plus the net lending position abroad minus foreign holdings of domestic capital. Domestic holdings on foreign capital are measured as direct plus portfolio equity investment by domestic agents abroad, while foreign holdings of domestic capital are measured as direct plus portfolio equity investment by foreign agents in the domestic economy. The net lending position abroad is equal to the sum of the net position in portfolio debt investment, the net position in other investment assets (including general government, banks, and others), reserve assets (minus gold), and the net position in financial derivatives.

The gross domestic capital stock in current US dollars for the countries in the sample is constructed using the procedure suggested by Kraay and Ventura (2000) in their Appendix $2 .{ }^{26}$ Gross domestic investment in current US dollars based on WBWDI is cumulated assuming a depreciation rate of $4 \%$ per year and by adjusting the value of the previous year's stock using the US gross domestic investment deflator. The initial capital stock in 1970 is estimated using the average capital-output ratio over the period 1965-1975 based on Nehru and Dhareshwar (1993) multiplied by the GDP in current US dollars based on WBWDI. The data on productive public spending are obtained from the Annual MacroECOnomic (AMECO) database of the European Commission's Directorate General for Economic and Financial Affairs and comprise the gross fixed capital formation from general government expressed in current euros and then transformed into current US dollars.

\section{Appendix B: Optimization}

The first step in solving the optimization problem is the introduction of a value function, $V(W)$, which is defined as

$$
V(W)=\operatorname{Max}_{\left\{C, n_{K}\right\}} E_{0} \int_{0}^{\infty} \frac{1}{\gamma} C^{\gamma} e^{-\beta t} d t,
$$

\footnotetext{
25 Please note that most of the data from IMFIFS, and from Lane and Milesi-Ferretti (2007) coincide for recent years.

26 See also Erauskin (2009) for more details on the data sources.
} 
Given initial wealth, this function is also subject to restrictions (16), (17) and (18). The value function in period 0 is the expected value of the discounted sum of instantaneous utilities, evaluated along the optimal path, starting in period 0 in state $W(0)=W_{0}$.

Starting from Eq. (30) the value function must satisfy the following equation, which is known as the Hamilton-Jacobi-Bellman equation of stochastic control theory or simply the Bellman equation

$$
\beta V(W)=\operatorname{Max}_{\left\{C, n_{K}\right\}}\left[\frac{1}{\gamma} C^{\gamma}+V^{\prime}(W) W \psi+0.5 V^{\prime \prime}(W) W^{2} \sigma_{w}^{2}\right] .
$$

The right-hand-side of Eq. (31) is partially differentiated with respect to $C$ and $n_{K}$ to obtain the first-order optimality conditions of the optimization problem

$$
\begin{aligned}
& C^{\gamma-1}-V^{\prime}(W)=0, \\
& V^{\prime}(W) W\left[(1-g) \Omega(g)-\left(i^{*}+\varepsilon\right)\right] \\
& +V^{\prime \prime}(W) W^{2} \operatorname{cov}[d w,(1-g) d y-d e]=0 .
\end{aligned}
$$

The solution to this problem is obtained through trial and error. We seek to find a value function $V(W)$ that satisfies, on the one hand, the first-order optimality conditions and, on the other hand, the Bellman equation. In the case of isoelastic utility functions, the value function has the same form as the utility function (Merton 1969, result generalized in Merton 1971). Thus, we postulate that the value function is of the form

$$
V(W)=A W^{\gamma}
$$

where the coefficient $A$ is determined below. This implies that

$$
\begin{aligned}
V^{\prime}(W) & =A \gamma W^{\gamma-1}, \\
V^{\prime \prime}(W) & =A \gamma(\gamma-1) W^{\gamma-2} .
\end{aligned}
$$

Inserting these expressions into the first order optimality conditions (32) and (34) we obtain

$$
\begin{gathered}
C^{\gamma-1}=A \gamma W^{\gamma-1}, \\
{\left[(1-g) \Omega(g)-\left(i^{*}+\varepsilon\right)\right] d t=(1-\gamma) \operatorname{cov}[d w,(1-g) d y-d e] .}
\end{gathered}
$$

Note that these are typical equations in stochastic models in continuous time. Equation (36) indicates that at the optimum, the marginal utility derived from consumption must be equal to the marginal change in the value function or the marginal utility of wealth. Equation (37) shows that the optimal choice of portfolio shares by the representative agent must be such that the risk-adjusted rates of the returns of both assets are equal. 
Combining Eqs. (36) and (37), and inserting them into Eq. (31), we can calculate the equilibrium portfolio shares and the consumption-wealth ratio in the open economy

$$
\begin{gathered}
n_{K}=\frac{(1-g) \Omega(g)-\left(i^{*}+\varepsilon\right)}{(1-\gamma) \Delta}+\frac{\sigma_{e}^{2}}{\Delta}, \\
n_{F}=1-n_{K}, \\
\frac{C}{W}=\frac{1}{1-\gamma}\left\{\beta-\gamma \rho+0.5 \gamma(1-\gamma) \sigma_{w}^{2}\right\},
\end{gathered}
$$

where

$$
\begin{gathered}
\Delta=(1-g)^{2} \sigma_{y}^{2}+\sigma_{e}^{2}, \\
\sigma_{w}^{2}=(1-g)^{2} n_{K}^{2} \sigma_{y}^{2}+n_{F}^{2} \sigma_{e}^{2} .
\end{gathered}
$$

\section{Appendix C: Second order conditions}

In this appendix, we derive the second order conditions and the transversality condition and show they all are satisfied.

To guarantee that consumption is positive in the open economy, we impose the feasibility condition that the marginal propensity to consume out of wealth must be positive because wealth cannot become negative

$$
\frac{1}{1-\gamma}\left\{\beta-\gamma \rho+0.5 \gamma(1-\gamma) \sigma_{w}^{2}\right\}>0
$$

For the first order optimality conditions to characterize a maximum, the corresponding second order condition must be satisfied, i.e., the Hessian matrix associated with the maximization problem and evaluated at the optimal values of the choice variables

$$
\left[\begin{array}{cc}
(\gamma-1)\left(V^{\prime}(W)\right)^{\frac{\gamma-2}{\gamma-1}} & 0 \\
0 & V^{\prime \prime}(W) W^{2} \Delta
\end{array}\right]
$$

must be negative definite, ${ }^{27}$ which implies that

$$
\begin{array}{r}
(\gamma-1)\left(V^{\prime}(W)\right)^{\frac{\gamma-2}{\gamma-1}}<0, \\
V^{\prime \prime}(W) W^{2} \Delta<0,
\end{array}
$$

$\overline{27}$ See Chiang (1984, pp. 320-323), for example. 
where $\Delta=(1-g)^{2} \sigma_{y}^{2}+\sigma_{e}^{2}>0$ was already defined in Eq. (41). To evaluate these conditions, we first obtain the value of the coefficient $A$ in Eq. (36)

$$
A=\frac{1}{\gamma}\left(\frac{C}{W}\right)^{\gamma-1},
$$

where $C / W$ is the optimal value generated by Eq. (40). Then, we substitute (43) into the value function (35). The value function is then given by

$$
V(W)=\frac{1}{\gamma}\left(\frac{C}{W}\right)^{\gamma-1} W^{\gamma} .
$$

We can observe that given the restrictions on the utility function, $V^{\prime}(W)>0$ and $V^{\prime \prime}(W)<0$ provided that $C / W>0$.

In addition, the macroeconomic equilibrium must satisfy the transversality condition

$$
\lim _{t \rightarrow \infty} E\left[V(W) e^{-\beta t}\right]=0
$$

so as to guarantee the convergence of the value function. Now we show that should the feasibility condition be satisfied, then this is equivalent to satisfying the transversality condition. ${ }^{28}$ To evaluate (45), we express the dynamics of the accumulation of wealth as follows

$$
d W=\psi W d t+W d w
$$

Starting with initial wealth $W(0)$, the solution to Eq. (46) is as follows ${ }^{29}$

$$
W(t)=W(0) e^{\left(\psi-0.5 \sigma_{w}^{2}\right) t+w(t)-w(0)} .
$$

Since the increments of $w$ are temporally independent and normally distributed then ${ }^{30}$

$$
\begin{aligned}
E\left[A W^{\gamma} e^{-\beta t}\right] & =E\left[A W(0)^{\gamma} e^{\gamma\left(\psi-0.5 \sigma_{w}^{2}\right) t+\gamma[w(t)-w(0)]-\beta t}\right] \\
& =A W(0)^{\gamma} e^{\left[\gamma\left(\psi-0.5 \sigma_{w}^{2}\right)+0.5 \gamma^{2} \sigma_{w}^{2}-\beta\right] t} .
\end{aligned}
$$

The transversality condition (45) is satisfied if and only if

$$
\gamma\left\{\psi-0.5 \gamma(1-\gamma) \sigma_{w}^{2}\right\}-\beta<0
$$

\footnotetext{
${ }^{28}$ See Merton (1969). Turnovsky (2000) provides, for example, proof of the transversality condition as well.

29 See Malliaris and Brock (1982, pp. 135-136), for example.

30 See Malliaris and Brock (1982, pp. 137-138) for example.
} 
Substituting Eqs. (19) and (40), this condition is equivalent to

$$
\frac{C}{W}>0
$$

and, thus, feasibility guarantees convergence as well.

Open Access This article is distributed under the terms of the Creative Commons Attribution Noncommercial License which permits any noncommercial use, distribution, and reproduction in any medium, provided the original author(s) and source are credited.

\section{References}

AMECO (Annual MacroECOnomic) database of the European Commission's Directorate General for Economic and Financial Affairs. http://ec.europa.eu/economy_finance/db_indicators/ameco/index_ en.htm. Accessed 7 June 2010

Andrés J, Doménech R, Fatás A (2008) The stabilizing role of government size. J Econ Dyn Control 32:571-593

Aschauer DA (1989) Is public expenditure productive? J Monet Econ 23(2):177-200

Barro RJ (1990) Government spending in a simple model of endogenous growth. J Polit Econ 98(5):S103S125

Cameron D (1978) The expansion of the public economy: a comparative analysis. Am Polit Sci Rev 72:1243-1261

Campbell JY (1996) Understanding risk and return. J Polit Econ 104(2):298-345

Chiang AC (1984) Fundamental methods of mathematical economics, 3rd edn. McGraw-Hill, Singapore

Corsetti G (1997) A portfolio approach to endogenous growth: equilibrium and optimal policy. J Econ Dyn Control 21:1627-1644

Doyle BM, Faust J (2005) Breaks in variability and co-movement of G-7 economic growth. Rev Econ Stat 87(4):721-740

Epifani P, Gancia G (2009) Openness, government size, and the terms of trade. Rev Econ Stud 76(2):629668

Erauskin I (2004) Three essays on growth and the world economy. Dissertation, University of the Basque Country, Bilbao, Spain

Erauskin I (2009) The current account and the new rule in a not-so-small open economy. Investig Econ 33(3):529-557

Erauskin I (2010) The impact of financial openness on the size of (utility-enhancing) government. Unpublished manuscript

Fatás A, Mihov I (2001) Government size and automatic stabilizers: international and intranational evidence. J Int Econ 55(1):3-28

Galí J (1994) Government size and macroeconomic stability. Eur Econ Rev 38(1):117-132

Garrett G (1995) Capital mobility, trade, and the domestic politics of economic policy. Int Org 49:657-687

Gramlich EM (1994) Infrastructure investment: a review essay. J Econ Lit 32:1176-1196

International Monetary Fund's International financial statistics 2008 (CD-ROM)

Kamien MI, Schwartz NL (1991) Dynamic optimization, 2nd edn. North-Holland, USA

Koethenbuerger M, Lockwood B (2010) Does tax competition really promote growth? J Econ Dyn Control 34(2):191-206

Kose MA, Prasad E, Rogoff K, Wei SJ (2006) Financial globalization: a reappraisal. IMF Working Paper WP/06/189. http://www.imf.org/external/pubs/ft/wp/2006/wp06189.pdf. Accessed 7 June 2010

Kraay A, Ventura J (2000) Current accounts in debtor and creditor countries. Q J Econ 115:1137-1166

Lane PR, Milesi-Ferretti GM (2007) The external wealth of nations mark II: revised and extended estimates of foreign assets and liabilities, 1970-2004. J Int Econ 73:223-250

Liberati P (2007) Trade openness, capital openness and government size. J Public Policy 27(2):215-247

Malliaris AG, Brock WA (1982) Stochastic methods in economics and finance. North-Holland, Amsterdam

Merton RC (1969) Lifetime portfolio selection under uncertainty: the continuous-time case. Rev Econ Stat 51:247-257. Reimpressed in Merton RC (1992) Continuous-time finance. Blackwell, Massachusetts 
Merton RC (1971) Optimum consumption and portfolio rules in a continuous-time model. J Econ Theory 3:373-413. Reimpressed in Merton RC (1992) Continuous-time finance, Blackwell, Massachusetts

Nehru V, Dhareshwar A (1993) A new database on physical capital stock: sources, methodology and results. Revista de Análisis Económico 8(1):37-59

Obstfeld M (1992) Dynamic optimization in continuous-time economic models (a guide for the perplexed). Working paper. http://emlab.berkeley.edu/users/obstfeld/index.shtml. Accessed 7 June 2010

Rebelo S (1991) Long-run policy analysis and long-run growth. J Polit Econ 99:500-521

Rodrik D (1998) Why do more open economies have bigger governments? J Polit Econ 106(5):997-1032

Schulze G, Ursprung HW (1999) Globalization of the economy and the Nation State. World Econ 22:295352

Turnovsky SJ (1997) International macroeconomic dynamics. MIT Press, Cambridge

Turnovsky SJ (1999) On the role of government in a stochastically growing open economy. J Econ Dyn Control 23:873-908

Turnovsky SJ (2000) Methods of macroeconomic dynamics, 2nd edn. MIT Press, Cambridge

World Bank's World Development Indicators 2007 (CD-ROM) 